\title{
THE USE OF ONLINE VIDEO SIMULATION ON STUDENT'S COMPETENCE, MOTIVATION AND ANXIETY LEVEL
}

\author{
Erna Rochmawati ${ }^{1 *}$, Fahni Haris ${ }^{1}$, Resti Yulianti Sutrisno ${ }^{1}$, Wulan Noviani ${ }^{1}$ \\ ${ }^{1}$ School of Nursing, Faculty of Medicine and Health Sciences, Universitas Muhammadiyah Yogyakarta, Yogyakarta - INDONESIA
}

Submitted: 26 Jun 2020; Final Revision from Author: 01 Mar 2021; Accepted: 18 Mar 2021

\begin{abstract}
Background: Nursing student often experience anxiety and lack of motivation during their training program particularly during examination, and this may affect the achievement of learning outcomes. Teaching methods that might increase motivation and potentially increase learning outcomes have been developed, including video simulation and online learning. The purpose of the study was to investigate the effects of integrating video simulation into online learning on students' motivation, anxiety level and competence.
\end{abstract}

Methods: A pre-test/post-test one group design was utilized. Two video simulations containing nursing skills were integrated into the e-learning system which can be accessed for three weeks by 76 respondents who took Basic Nursing course. The level of motivation and anxiety were measured before and after the intervention, while the competence was measured after the intervention.

Results: The majority of students passed the skills examination. This study indicates a significant increase of students' motivation after the intervention ( $p$ value $<0.001$ ), but the level of anxiety among respondents increased.

Conclusion: The integration of video simulation into e-learning system can enhance student's skills performance and motivation. Although there is also an increase in anxiety, findings of the study can be applied to other subjects and nursing skills with attention to aspects that cause student anxiety.

Keywords: anxiety; e-learning; motivation; nursing skills; nursing student; video simulation

\section{ABSTRAK}

Latar belakang: Mahasiswa keperawatan sering mengalami kecemasan dan kurang motivasi selama program Pendidikan mereka terutama selama ujian, dan ini dapat mempengaruhi pencapaian hasil belajar. Metode pengajaran yang dapat meningkatkan motivasi dan berpotensi meningkatkan hasil pembelajaran telah dikembangkan, termasuk simulasi video dan pembelajaran online. Tujuan dari penelitian ini adalah untuk menyelidiki efek dari mengintegrasikan simulasi video ke dalam pembelajaran online pada motivasi, tingkat kecemasan dan kompetensi siswa.

Metode: Penelitian ini menggunakan desain pre-test / post-test pada satu kelompok. Dua video simulasi yang berisi keterampilan keperawatan diintegrasikan ke dalam sistem e-learning yang dapat diakses selama tiga minggu oleh 76 responden yang mengambil blok Keperawatan Dasar. Tingkat motivasi dan kecemasan diukur sebelum dan sesudah intervensi, sedangkan kompetensi diukur setelah intervensi.

*corresponding author, contact: erna.rochmawati@umy.ac.id 
Hasil: Mayoritas siswa lulus ujian keterampilan. Penelitian ini menunjukkan peningkatan motivasi siswa yang signifikan setelah intervensi (nilai p <0,001), namun terdapat peningkatan kecemasan pada responden.

Kesimpulan: Integrasi simulasi video ke dalam sistem e-learning dapat meningkatkan kinerja keterampilan dan motivasi siswa. Meskipun ada juga peningkatan kecemasan, temuan penelitian ini dapat diterapkan pada mata pelajaran lain dan keterampilan keperawatan dengan memperhatikan aspek-aspek yang menyebabkan kecemasan siswa.

Kata kunci: e-learning; kecemasan; ketrampilan keperawatan; mahasiswa keperawatan; motivasi; video simulasi

\section{PRACTICE POINTS}

- Integration of video simulation into electronic learning system can be used as one of strategies to improve student's performance on nursing skills.

- Opportunity to see the video simulation can increase nursing student's motivation.

- Nurse educator should concern on student' anxiety during simulation and examination.

\section{BACKGROUND}

The provision of quality and safety of care is fundamental in the delivery of nursing care. Nurses must be able to provide such care while confront with the increased of patient's needs and complexity of care within limited resources. During the training program, nursing students have to pass competency examination either in cognitive, psychomotor skills and affective, and this often cause them to experience anxiety and lack of motivation. ${ }^{1}$ For example, in a study it was found that nursing students experience signs of anxiety during laboratory practice including tremors, swearing, having cold skin, and feeling fear. ${ }^{2}$ Nursing students have higher anxiety during the training program compared to students from other disciplines due to many examinations that they must pass. ${ }^{3}$ Anxiety and lack of motivation influence student's clinical competence either increase or decline the competence. ${ }^{4}$ These challenges charge educational institutions including lecturers in preparing competent nurses who are able to provide quality nursing care. In addition, the lecturers should be able to implement innovative teaching strategies that can enhance student's clinical skills competency, clinical judgment as these skills can be acquired through learning. The teaching methods should enable to engage student nurse in the learning process and introduce them to simulated situations that is close to real clinical situation they will routinely encounter. The strategies could be using simulations and online learning., ${ }^{5,6}$ Available literature indicated many advantages of using online learning and simulations on the learning process and learning outcomes. For example, a systematic review found that e-learning has positive impacts to student's learning outcomes, although such outcomes are very situational. ${ }^{6}$ A literature search that has been conducted found none studies have investigated effects of integrating simulations, particularly video simulation into online learning.

Simulation is one of the teaching strategies that mimic the reality of clinical environment in a controlled environment. ${ }^{5,7}$ In health education institutions, simulations are used for learning, research and evaluation to meet demands in clinical practice and the complex challenges of health problems. ${ }^{8}$ Many studies have been conducted to investigate effects of simulations in healthcare institution and find both benefit and disadvantage in its use. Previous studies have shown that clinical simulation can improve 
student's nurse communication skills and clinical skills. ${ }^{9-11}$ Another benefit of clinical simulations is an increased of student motivation, particularly among novice nursing students. ${ }^{12}$ In addition, clinical simulation is associated with less anxious and stress, being more emotionally prepared and better achievement, and having higher motivation among students. ${ }^{2,12}$

One type of simulation is the use of video simulation, that is defined as the use of interactive videos to show a given procedure simulated on a manikin or a simulated patient that mimic the reality of clinical situation. ${ }^{13,14}$ For this type of simulation, the video is provided to students so that they access and watch as the necessary. The video is an additional teaching materials to can be used before attending practical activities in simulation center, and relevant to today's student. ${ }^{15}$ Video simulation has several benefits including: being more practical and cost-efficient, and have higher impact in learning particularly in communication and technical skills. ${ }^{13,14,16}$ In addition, Dyer et al found from their study state that video simulation is effective to be implemented in low resource settings. ${ }^{17}$ Yet, today there is still lacked studies investigating the efficacy of using video simulations in education in low resource settings such as in Indonesia.

Available literatures demonstrate that test anxiety is prevalent among student nurse, and it can negatively affect their academic performance. ${ }^{3,18}$ Several causes of text anxiety has been identified including; being less prepared, having insufficient knowledge of the test material, having inaccurate perceptions of the test. ${ }^{19}$ In addition, teaching methods might also increase the anxiety. For example, in clinical simulations students is expected to be self-directed, and this may increase student anxiety. ${ }^{5,20}$ Anxiety during simulation particularly in high-fidelity simulation is identified related to poor performance in previous studies. ${ }^{4,20}$ Identified strategies to reduce the anxiety include: conducting preparatory workshop, providing sufficient time for simulation, and improving interactions with low-fidelity manikins. $^{20,21}$ In addition, differentiated forms of teaching methods should be considered to promote nurse students' competency while improving their motivation and reducing their anxiety. ${ }^{22,23}$

Among the strategies are the integration of online learning and video simulation. ${ }^{14,24}$ Online learning can be defined as a learning activity using computers to engage student in academic content by combining instructional design and contents. ${ }^{25}$ Online learning has been globally implemented in the higher education, both developed and developing countries because of its flexibility in providing student-centered education. ${ }^{24}$ Many studies show the benefits of using e leaning on students. For example, systematic review indicates that e-learning has an effect on student learning outcomes, although the learning outcomes are very situational. ${ }^{6}$ In addition, a study at a university in Iran showed e-learning had a positive effect on students' motivation. ${ }^{24}$ Online learning is associated with an improved in student's clinical skills development. ${ }^{26}$

In the school of nursing where the current study is conducted, online learning is implemented mostly asynchronous where students can access learning resources such as lecture notes and references. The students also can join discussion in the forum. In the study, we develop two video simulations and integrate them into the online learning. The study aimed to investigate the effects of integrating video simulation into online learning on motivation, anxiety, and skills competency among undergraduate nursing students.

\section{METHODS}

The study utilized one group pretest-posttest design to evaluate the effect of integrating video simulation into online learning on student's motivation, anxiety and skills competence.

\section{Setting and samples}

The study was conducted in a private School of Nursing in Indonesia. Purposive sampling was used to recruit respondents. Inclusion criteria were nursing students who enrolled in the Basic Nursing course and had no previous clinical practice. The total sample was 79 students of 126 eligible students. The pretest and posttest design was utilized as the 
study intended to measure effects of integrating the video simulation in online learning, particularly on the competency, level of anxiety and motivation. The nursing skills competency was measured after the implementation, while the level of motivation and the anxiety were measured before and after the interventions.

\section{Measurement/instruments}

The level of anxiety and motivation were measured before and after the interventions. Anxiety was measured using the Indonesian version of the Nursing Skills Anxiety Test Scale (NSTAS) which has been validated, an instrument that was developed to measure stress level specifically among nursing students. ${ }^{27}$ The instrument to measure student motivation consists of 15 items that measure source of motivation, and behavior related to motivation. The measurement using Likert Scale, from never (0) to always (3).

Student's skills performance was measured by OSCE using manikin. The evaluation during OSCE was conducted using skills checklist and OSCE brief scenarios. The nursing skills performance included range of motion and injection which included preparation, performing the skills and documentation with a correct sequence. The checklist procedure using a Likert scale: (2) good, (1) average, (0) poor; higher scores indicated a higher level of skills. The minimum score to pass the OSCE is 80 .

We developed two videos of nursing skills that taught in the Basic Nursing course; range of motion and intravenous and intramuscular injection. Each video contains the following topics: purpose of the skills; indication and contraindications; and procedures to do the skills. We followed Cardoso et al' steps to produce the videos: pre-production, production and post-production. In the pre-production phase, we identified and choose nursing skills that usually many students failed. Afterwards, the researchers together with the professional team from the advertising field conducted the video recording. ${ }^{14}$ The video was recorded in digital format by a professional team from advertising field, and then was validated by the researchers. The video validation was conducted by considering audiovisual technique and procedure simulations. All the researchers agreed on the relevance, some suggestions were made including to add running text in some scenes and reduce the duration of the video. Following this, the videos were uploaded in the online learning system so that the students can watch as they necessary.

\section{Data collection and procedures}

The study was approved by the institutional Research Ethics Committee (No. 404/EP-FKIKUMY/VII/2017). The recruitment was conducted by the researcher by posting a recruitment notice in student social media group. Students who were interested to participate were provided with study materials that include information sheet, a consent form and self-reported questionnaires. Participation in the study was voluntary and did not affect on the students' grading. In the study, ethical principles were maintained by explaining goals to the respondents, obtaining informed consent and ensuring respondents' autonomy, anonymity and confidentiality.

After consenting to participate in the study, participants were able to access video-based simulation in their online learning account for three weeks. The nurse students watched video simulation practice on these skills: injections and range of motion, and also had a 2-hour skills laboratory session. The skills laboratory session covered overview of the skills and direct demonstration in a mannequin by the laboratory instructor. During the laboratory session, students were asked to have practical demonstration in a mannequin.

Motivation and anxiety were measured before and after the intervention using validated questionnaire. Nursing skills performance were measured after the intervention during the nursing skills examination using standardized performance checklist during Objective Structured Clinical Skills Examination (OSCE). After three weeks, the participants completed the motivation and anxiety questionnaires. Information from skills competence was synthesized using descriptive statistics. The results from the preand postintervention questionnaires were tested using paired t-test to determine if there are differences in motivation and anxiety level. 


\section{RESULTS AND DISCUSSION}

The study included 79 students. Table 1 provides baseline and postintervention scores of motivation and anxiety. As shown, there is an increased in anxiety score, from 16.38 in base line to 19.46 in post intervention. There is a statically significant difference between baseline and posttest for the student's anxiety. In relation to the level of motivation, the result indicates an increasing mean score in pretest and posttest, from 42.42 to 46.78 , and it is statically significant (Table 2).

Table 1. Distribution of scores on motivation and anxiety before and after the educational video $(n=79)$

Variables Mean SD Median Min-max

Motivation

\begin{tabular}{ccccc} 
Pre & 42.42 & 4.746 & 42 & $32-54$ \\
Post & 46.78 & 5.782 & 47 & $36-66$ \\
Anxiety & & & & \\
Pre & 16.38 & 3.560 & 16 & $6-24$ \\
Post & 19.46 & 3.576 & 20 & $12-28$ \\
\hline
\end{tabular}

Table 2. Mean Differences on motivation and anxiety level before and after the integration of video-based simulation into e-learning

\begin{tabular}{cccc} 
Variables & Mean & Delta mean & P \\
Motivation & & & \\
Pre & 42.42 & 4.36 & 0.000 \\
Post & 46.78 & & \\
Anxiety & & & \\
Pre & 16.38 & 3.08 & 0.000 \\
Post & 19.46 & & \\
\hline
\end{tabular}

The average score of student skills competence in conducting injection procedure was 81.03, with score ranged from 54.70-93.90. The mean score that obtained by students in the procedure of range of motion skills was 75.53, varied from 41-94.73. Table 3 shows that in relation to passing rate on both procedures, $94.7 \%$ students passed on the procedure of injection, while only $72.4 \%$ passed on the procedure of range of motion.
Table 3. Distribution of scores on procedures of injection and range of motion

\begin{tabular}{lccc} 
Procedures & $\begin{array}{c}\text { Frequency } \\
\text { percentage } \\
(\mathrm{f}, \%)\end{array}$ & Mean & Min-max \\
& & 81.03 & $54.70-93.90$ \\
Injection & $72,94.7 \%$ & & \\
$\quad$ Pass & $4,5,3 \%$ & & \\
Fail & & 75.53 & \\
Range of motion & $55,72.4 \%$ & & $41.00-94.74$ \\
$\quad$ Pass & $21,27.6 \%$ & & \\
$\quad$ Fail & & & \\
\hline
\end{tabular}

Rapid changes in technology and information affects health services and nursing education process. This development indirectly encourages higher nursing education institutions conduct breakthrough in the application of information technology. Nursing education programs that trained many nursing procedural skills are required to develop the learning methods. One of methods is using simulation to provide experience to students in the real context in order to improve students' competence and confidence. ${ }^{12,28}$ In addition, the development of information technology requires educational institutions to apply online learning as one of the teaching methods. This study aimed to determine the application of integration of video simulation into e-learning to the skills competence, motivation and anxiety level of nursing students.

Previous studies have focused only one type of simulation or e-learning, but still limited studies incorporated simulations into e-learning. Poikela et al state that the incorporation of online learning with conventional teaching methods and blended learning is associated with improved students' motivation and academic competence. ${ }^{29}$ In this study, video simulations were incorporated into e-learning system and tested on the second year students.

This study indicates that student's motivation increased significantly after the interventions. Thus, integrating video simulation into the e-learning system can be one of suitable teaching methods to teach nursing skills procedures, particularly injection and range of motions. Previous study that investigate the use of video in teaching strategy shown its 
success. A study that explores students' perceptions of simulations also found an increase in student motivation by applying the simulated learning process. ${ }^{30}$ Another study was conducted by Bravo et al among 487 engineer students. ${ }^{31}$ In their study, focused videos with the duration of approximately 4 minutes that broadcasted in web-integrated teaching platform and YouTube channels. ${ }^{31}$ These authors found that the use of videos has shown increasing motivation among engineer students. Similar with the present study, engineer students in the previous study can access the videos in their own times and this may the factor that increase the student's motivations. ${ }^{31}$ In addition to accessibility, it was stated that combining simulations with e-learning can improve the students' motivation in the early semester to develop their skills so that they will be better prepared when practicing in the clinic. ${ }^{29}$ In line with previous studies, the increasing motivation in the present study can be caused by the accessibility of video in their time and student's year level.

In addition to motivation, this study also measured students' anxiety levels. Student's anxiety due to test and examination remains become a problem in the education, even such anxiety is defined separately into a disorder of concentration, memory, focus, physical health, emotions and potential individuals. The current study indicates the level of student anxiety increased after the intervention. Experiences during simulation can cause anxiety, even the level of anxiety during the simulation learning process can be the same as when faced with the examination. A review conducted by Nielsen and Harder that seek students' anxiety during the simulation process identified several factors related to anxiety, including learning style, felt observed by lecturers or friends and time constraints. ${ }^{20} \mathrm{An}$ increased anxiety in the current study might be influenced by several things. The anxiety might be the time of measuring the anxiety level, where in this study the students were asked to fill out the questionnaire before the examination. In addition, increasing anxiety is associated with being observed by the lecturers, being inexperienced, and being less prepared for a simulation activity. ${ }^{4}$

Anxiety that experienced by students can lead to a decrease in learning outcomes, therefore intervention should be done to reduce the anxiety level. A study that explored possible interventions to reduce student's anxiety using mixed methods study found several possible interventions. ${ }^{32}$ Such interventions include; skill review prior to simulation, looking back during the skills practice, minimizing comments either from lecturers or friends during the simulation and providing appropriate feedback.

In this study, video-based simulation was integrated into e-learning system so students can access and repeat viewing the nursing skills procedures many times at their own time. The results of this study indicate a high degree of passing on injection skills. Simulation can increase student's knowledge particularly in low stakes simulation. ${ }^{33}$ This can be due to types of procedures. Procedure on injection is a procedure that many students are fear off, so it is likely that the students encourage to learn and practice more, and focus in this procedure and this. Although not directly observed in this study, the high passing rate on these skills is consistent with previous study that identified self-directed learning affected on student's clinical competence..$^{34}$ In relation to the rate of passing, the opposite condition is occurred in the procedure of range of motion skills, where the passing rate and the mean score are lower than the procedure on injection. A study conducted by Hansen comparing student's competencies before and after given video of catheter-fixing skills via iPod found no significant difference in student competence after the intervention. ${ }^{35}$ Compared with injection skills, procedure on range of motion is relatively simpler despite more stages. In this study, the high level of insufficiency in such procedure can be attributed that the student focus on learning of more difficult skills, resulting in a lack of time to focus on more simple procedures.

\section{CONCLUSION}

It can be concluded that the integration of vide simulation into e-learning can improve student motivation and student pass rate on very high injection skill. However, in this study also found an increase in student anxiety. For educational institutions should consider the level of student anxiety because it can affect the final exam results. 
In the learning process during the clinical laboratory it can be applied interventions such as debriefing to reduce student anxiety. For further research can see the effect of this intervention on improving clinical reasoning students.

\section{RECOMMENDATION}

The results of this study developed the knowledge that simulations, especially video-based simulations can not only improve clinical reasoning skills and clinical reasoning of students, but also improve student motivation to learn and achieve. Taking into account the cultural background and health service system, the positive outcomes in this study can provide new discourse in using technology to improve the quality of nursing education.

\section{COMPETING INTERESTS}

The authors declare that there are no competing interests related to this study.

\section{AUTHORS' CONTRIBUTION}

Erna Rochmawati - study design and conception, data analysis, manuscript write and revisions for intellectual content.

Fahni Haris - data collection, manuscript write for intellectual content.

Resti Yulianti Sutrisno - data collection, Data analysis, manuscript write for intellectual content.

Wulan Noviani - data collection, manuscript write for intellectual content.

\section{REFERENCES}

1. Tuzer H, Dinck L, Elcin M. The effects of using high-fidelity simulators and standardized patient on the thorax, lung, and cardiac examination skills of undergraduate nursing students Nurse Educ Today. 2016; 45: 120-125.

2. Boostel R, Felix JVC, Bortolato-Major C, Pedrolo E, Vayego SA, Mantovani MdF. Stress of nursing students in clinical simulation: a randomized clinical trial. Revista Brasileira de Enfermagem. 2018; 71(3): 967-974.
3. Driscoll R, Evan G, Ramsey F, Wheeler S. High test anxiety among nursing students. Tenesse: University of Tenesse; 2009.

4. Al-Ghareeb A, Cooper S, McKenna L. Anxiety and clinical performance in simulated setting in undergraduate health professionals education: An integrative review. Clinical Simulation in Nursing. 2017; 13: 478-491.

5. Jeffries P. A framework for designing, implementing and evaluating simulations used as teaching strategies in nursing. Nursing Education Perspective. 2007; 26(2): 96-103.

6. Voutilainen A, Saaranen T, Sormunen M. Conventional vs e-learning in nursing education: A systematic review and meta-analysis. Nurse Education Today. 2017.

7. Gaba D. The future vision of simulation in healthcare. Simul Healthc. 2007; 2(2): 126-135.

8. Alinier G, Harwood C, Harwood P, et al. Immersive clinical simulation in undergraduate health care interprofessional education: knowledge and perceptions. Clinical Simulation in Nursing. 2014; 10(4): e205-216.

9. Lapkin S, Levett-Jones T, Bellchambers H. The development and psychometric testing of the Satisfaction with Simulation Experience Scale. Clin Simul Nurs. 2010; 6(6): e207-e222.

10. Blum CA, Borglund S, Parcells D. High-Fidelity Nursing Simulation: Impact on Student SelfConfidence and Clinical Competence. Int J Nurs Educ Scholarsh. 2010; 7(1).

11. Kameg K, Howard VM, Clochesy J, Mitchell AM, Suresky JM. he Impact of High Fidelity Human Simulation on Self-Efficacy of Communication Skills. T Issues Ment Health Nurs. 2010; 31: 315-323.

12. Fawaz MA, Hamdan-Mansour AM. Impact of high-fidelity simulation on the development of clinical judgment and motivation among Lebanese nursing students. Nurse Educ Today. 2016; 46: 36-42.

13. Sharpnack PA, Goliat L, Baker JR, Rogers K, Shockey $P$. Thinking like a nurse: using video simulation to rehearse for professional practice. Clinical Simulation in Nursing. 2013; 9(12): e571-e577. 
14. Cardoso AF, Moreli L, Braga FTTM, Vasques CI, Santos CB, Carvalho EC. Effect of a video on developing skills in undergraduate nursing students for the management of totally implantable central venous access ports. Nurse Education Today. 2012; 32: 709-713.

15. Da Silva C, Peisacovich E, Gal R, Anyinam C, Coffey S, Graham L. A Programmatic Approach to the Design of a Video Simulation Case Study. Clinical Simulation In Nursing. 2020; 41: 1-8.

16. Pinar G, Abay H. The Effect Of Video Based Simulation Training On Neonatal Examination Competency Among Turkish Nursing Students. European Scientific Journal 2016; 12(15): 394-405.

17. Dyer J, Spindler H, Christmast A, et al. Video Monitoring a Simulation-Based Quality Improvement Program in Bihar, India. Clin Simul Nurs. 2018; 17: 19-27.

18. Shapiro AL. Test anxiety among nursing students: A systematic review. Teaching and Learning in Nursing. 2014; 9(4): 193-202.

19. Beggs C, Shields D, Janiszewksi GH. Using guided reflection to reduce test anxiety in nursing students. J Holist Nurs. 2011; 29: 140-147).

20. Nielsen B, Harder N. Causes of student anxiety during simulation: What literature says. Clinical Simulation in Nursing. 2017; 9(11): e507-e512.

21. Parkin V, Cherney S, Soriano A. A preparatory workshop to reduce student anxiety prior to clinical testing. Teaching and Learning in Nursing. 2020; 15(1): 12-14.

22. $\mathrm{Xu} \mathrm{J}$. Toolbox of teaching strategies in nursing Chinese Nursing Research. 2016; 3(2): 54-57.

23. de Souza Teixeira C, Kusumota L, Pereira M, et al. Anxiety and performance of nursing students in regard to assessment via clinical simulations in the classroom versus filmed assessments. Invest Educ Enferm. 2014; 32(2): 270-279.

24. Harandi SR. Effects of e-learning on students' motivation Procedia-Social and Behavioural Sciences. 2015; 181: 423-430.

25. Kala S, Isaramalai S-a, Pohthong A. Electronic learning and constructivism: A model for nursing education. Nurse Education Today. 2010; 30(1): 61-66.
26. Barisone M, Bagnasco A, Aleo G, et al. The effectiveness of web-based learning in supporting the development of nursing student's practical skills during clinical placements: A qualitative study. Nurse Educ Pract. 2019.

27. Yang RJ, Lu YY, Chung ML, Chang SF. Developing a short version of the test anxiety scale for baccalaureate nursing skills test-a preliminary study. Nurse Education in Practice. 2014; 14(6): 586-590.

28. Yuan HB, Williams BA, Fang JB. The contribution of high-fidelity simulation to nursing students' confidence and competence: a systematic review. International Nursing Review. 2012; 59(1): 26-33.

29. Poikela P, Ruokamo H, Teras M. Comparison of meaningful learning characteristics in simulated nursing practice after traditional versus computer-based simulation method: A qualitative videography study. Nurse Education Today. 2015; 35(2): 373-382.

30. Botma Y. Nursing student's perceptions on how immersive simulation promotes theory-practice integration. International Journal of Africa Nursing Sciences. 2014; 1: 1-5.

31. Bravo E, Amante B, Simo P, Enache M, Fernandez $\mathrm{V}$. Video as a new teaching tool to increase student motivation Paper presented at: Global Engineering Education Conference (EDUCON). 2011.

32. Cato ML. Nursing student anxiety in simulation settings: A mixed-method study. Portland, Portland State University. 2013.

33. Burbach BE, Struwe LA, Young L, Cohen MZ. Correlates of Student Performance during Low Stakes Simulation. J Prof Nurs. 2019; 35(1): 4450.

34. Do ES, Seo YS. Factors influencing clinical competence in nursing students. Journal of Korean Academy of Fundamentals of Nursing. 2014; 21(3): 283.

35. Hansen MM. Are nursing students' clinical skills competency and self-confidence levels improved via video iPods? A randomized controlled pilot study. Journal of Nursing Education and Practice. 2011; 1(1): 32-42. 